\title{
Subsidiary Brands as a Resource and the Redistribution of Decision Making Authority following Acquisitions
}

\author{
Dieng, Sebastian; Dörrenbächer, Christoph; Gammelgaard, Jens
}

\author{
Document Version \\ Final published version
}

Publication date:

2008

License

CC BY-NC-ND

Citation for published version (APA):

Dieng, S., Dörrenbächer, C., \& Gammelgaard, J. (2008). Subsidiary Brands as a Resource and the Redistribution of Decision Making Authority following Acquisitions. Department of International Economics and Management, Copenhagen Business School. Working Paper / Department of International Economics and Management, Copenhagen Business School No. 2-2008

Link to publication in CBS Research Portal

\footnotetext{
General rights

Copyright and moral rights for the publications made accessible in the public portal are retained by the authors and/or other copyright owners and it is a condition of accessing publications that users recognise and abide by the legal requirements associated with these rights.

\section{Take down policy}

If you believe that this document breaches copyright please contact us (research.lib@cbs.dk) providing details, and we will remove access to the work immediately and investigate your claim.
} 
Working Paper from the Copenhagen Business School: Department of International Economics and Management: Center of International Business and Innovation: 8. September 2008.

\title{
Subsidiary Brands as a Resource and the Redistribution of Decision Making Authority following Acquisitions
}

\author{
Sebastian Dieng* \\ Christoph Dörrenbächer**,\# \\ Jens Gammelgaard***
}

* School of Management, University of Surrey, Guildford,GU2 7XH,UK, ++41 1483 683102 s.dieng@ surrey.ac.uk

** University of Groningen; Department of International Business \& Management, Landleven 5, P.O. Box 800, 9700 AV Groningen, The Netherlands; Phone: ++ 3150363 7338 (university office) Phone: ++ 494919992963 (home office), Fax ++ 3150363 3720, c.dorrenbacher@rug.nl

*** Copenhagen Business School, Department of International Economics and Management / Porcelænshaven 24, DK-2000 Frederiksberg, Denmark, Phone: +45 38152512, jg.int@cbs.dk

\# corresponding author 


\title{
Subsidiary Brands as a Resource and the Redistribution of Decision Making Authority following Acquisitions
}

\begin{abstract}
This paper analyses the moves global brewery companies undertake towards the distribution of decision making authority in their multinational organization and the likelihood of newly acquired subsidiaries to influence these moves. In this consumer goods industry, brands are suggested to be the primary subsidiary specific resource to influence these distribution processes. Empirically this paper explores three European acquisitions of the Dutch brewery corporation Heineken in Switzerland, Slovakia, and France. We explore whether differing brand value (regional/international, standard/premium) has had an impact on the subsidiaries' ability to maintain a certain degree of decision making authority after the take-over. The results of our case studies show, however, that the ownership of valuable brands may not be considered as a critical resource for subsidiaries here.
\end{abstract}

\section{Key words}

Subsidiary resources, Decision making authority, Decentralization, Headquarters-subsidiary relationships, Brewery industry, Brands, Heineken. 


\title{
Subsidiary Brands as a Resource and the Redistribution of Decision Making Authority following Acquisitions
}

\begin{abstract}
This paper analyses the moves global brewery companies undertake towards the distribution of decision making authority in their multinational organization and the likelihood of newly acquired subsidiaries to influence these moves. In this consumer goods industry, brands are suggested to be the primary subsidiary specific resource to influence these distribution processes. Empirically this paper explores three European acquisitions of the Dutch brewery corporation Heineken in Switzerland, Slovakia, and France. We explore whether differing brand value (regional/international, standard/premium) has had an impact on the subsidiaries' ability to maintain a certain degree of decision making authority after the take-over. The results of our case studies show, however, that the ownership of valuable brands may not be considered as a critical resource for subsidiaries here.
\end{abstract}

\section{Key words}

Subsidiary resources, Decision making authority, Decentralization, Headquarters-subsidiary relationships, Brewery industry, Brands, Heineken. 


\section{Subsidiary Brands as a Resource and the Redistribution of Decision Making Authority following Acquisitions}

\section{Introduction}

The world beer industry is in great flux. Stagnation of traditional beer markets in Western Europe and North America on the one hand and a strong and growing demand in the emerging markets of the Eastern Europe and China on the other hand puts among others an emphasis on the distribution of strategic decision-making authority in multinational breweries. The management of global brands speaks for centralization whereas the manifold local beer brands call for a decentralisation of decision-making authority regarding marketing and sales activities.

Furthermore, mergers and acquisitions play a dominant role in the global beer industry. They lead to a quick access to markets and especially to the brands owned by the target firms. Simultaneously they enlarge the possibility of global brand utilization. This paper questions whether acquired firms in the brewery sector keep their decision-making authority regarding their brand and marketing activities, or whether headquarters of the acquiring multinational corporation (MNC) centralizes such strategic decisions. In a wider sense, the paper investigates the relationship between subsidiary resources and the strategic developments of subsidiaries in the context of an MNC.

Given the overall importance of the acquisition-integration dichotomy in the industry, this paper contributes with a high practical relevance to managers in the field (Oesterle and Laudin, 2007). Its practical relevance is driven by a research question that addresses the effective functioning of an MNC. Hereby we depart our investigation from a phenomenon, as suggested by Cheng (2007), rather than testing one 'theory of the firm' in the context of the 
brewery sector. Instead, we discuss the concept of decision-making authority in relation to decentralisation on the one hand, and acquisition-integration on the other. Investigating the distribution of decision making authority in the $\mathrm{MNC}$, further, makes it possible to discuss relevance of global versus local leadership.

In its empirical part the paper concentrates on Heineken of the Netherlands and three of its subsidiaries acquired in Switzerland, Slovakia, and France throughout the 1990ies. This sample enables a comparative angle on European management research, as proposed by Mayrhofer (2007). We, further, emphasize the European perspective by describing the foreign direct investment of a European company, focusing on acquisitions as entry mode.

In the reminder the paper first provides a brief discussion of the literature dealing with the distribution of decision making authority in MNCs and put this concept into the perspectives of centralization and acquisition strategy. Following some methodological annotations, the paper then turns to its empirical part. First, Heinekens overall integration strategy that aims at a strong centralization is studied. This is followed by a detailed investigation into the integration process of three recently acquired European subsidiaries of Heineken that vary considerably with regard to brand ownership. The paper closes with some assumptions as to what extent decision making authority in newly acquired subsidiaries remains decentralized and in how far brands form a basis for resisting headquarters' centralization attempts.

\section{Literature Review}

Subsidiary decision making authority is often associated with the concept of autonomy, and researchers like O'Donnell (2000) define autonomy as the degree of decision making a subsidiary maintains. However, as Young and Tavares (2004) have shown, subsidiary autonomy can be conceptualized rather broadly as it might be associated with a.o.: subsidiary 
role, network position, entrepreneurship, procedural justice, and control. In order to keep our analysis focused, this paper only investigates whether acquired firms keep their right to make decisions regarding their brands and related marketing strategies following their take-over. Thus, decision making authority, defined by Goehe (1980:20) as the “...zone of discretion in making programmed or basic decisions as well as non-programmed or routine decisions", is the concept being investigated.

Traditionally, MNCs have been viewed as hierarchical entities where decision-making authority resided strongly within headquarters (Dunning, 1958). Later, Franko (1976) demonstrated that European MNCs to a higher degree decentralised decision-making than American MNCs. This empirical evidence paved the way for approaches in which decision making authority was considered to be more evenly distributed between headquarters and subsidiaries. For instance Hedlund (1986) argued that MNCs need to be seen as "heterarchies" which have more than one centre and in which individual subsidiaries might be given strategic decision-making authority not only for their own subsidiary but for the whole MNCs. However, other researchers like Kotthoff (2001) show a (re)centralization of strategic decision-making occurring in (German) MNCs.

The fuzziness of the results should not come as a surprise, given fact that there are many simultaneously valid reasons for centralization and decentralisation of authority. Reasons in favour of a decentralization of decision making encompass the information overload at the top management in the headquarters, the need for local responsiveness at foreign operations, the desire to tap into local knowledge and the wish to motivate and reward subsidiaries (Baliga and Jaeger, 1984). Reasons that limit the decentralization of decision making authority comprise headquarters' desire to keep financial control, overall strategic authority and a final say in the shape of products, processes and corporate values. Furthermore, the 
discussion of centralisation versus decentralisation has been associated to country-of-origin effects (Gates and Egelhoff, 1986), industry (Bartlett and Ghoshal, 1989), and function (McKern and Naman, 2003). Wirth regard to the latter, Vachani (1999) has demonstrated that subsidiary decision-making authority was greater for marketing than for $\mathrm{R} \& \mathrm{D}$ or finance. Finally, the issue of control is associated to this question (O'Donnell, 2000), as decision-making rights might be decentralized, but in practice decisions are often made by expatriates that monitor and align activities to headquarters' preferences (Doz and Prahalad, 1981).

What is most likely to impact decision-making authority is, though, the control of resources upon which other MNC entities depend since they are critical to the overall performance of the company (Pfeffer and Salancik, 1978). Based on the distinctiveness of its resources a subsidiary can gain different levels of power and independency from headquarters (Bouquet and Birkinshaw, 2008). Following Rugman and Verbeke (2001), such critical resources have some basic features: They incorporate knowledge that is tacit and fundamentally context specific, i.e. locally embedded and path dependent on the subsidiaries technological and organizational trajectory. Extant research has proven that specific technologies and product portfolios (Egelhoff et al., 1998) learning capabilities (Mu et al, 2007), entrepreneurial and managerial expertise (Birkinshaw and Hood, 1997) and internal R\&D processes (Papanastassiou and Pearce, 2005) might turn out as critical resources that strongly empower subsidiaries vis-a-vis their headquarters.

Remarkably little, however, is known about marketing resources and in particular about the role of brands as a critical resource. This is a major shortcoming of the literature since brands play a particular important role in consumer driven industries such as the beer industry. Brands are the key to the customers, and initial market access via established brands is a key 
driver of the acquisition merry-go-around in the global brewery industry (Marinov and Marinova, 1999; Meyer and Tran, 2006; Meyer, 2007). The key question here is, in how far brands might turn out as critical resources that empower acquired subsidiaries vis-a-vis their new headquarters.

The context of an acquisition adds another dimension, as the subsidiary brand value has been developed before the take-over. A literature review by Young and Tavares (2004) shows that acquired subsidiaries are likely to have greater decision-making authority because of these path-dependent historical conditions. Haspeslagh and Jemison (1991) here suggest different integration strategies, where the level of decision-making authority is emphasized. High level of decision-making authority is recommended in the situation of subsidiary specific resources that are likely to be destroyed if integrated too roughly, and e.g., key people are likely to leave the firm (Paruchuri et al, 2006). In other situations, the acquiring firm is recommended to absorb the target firm in order to reveal synergy and leave the new subsidiary with little decision-making authority. Though, recently, Schweizer (2005) has shown that different integration strategies can be associated to different value chain activities, by which the subsidiary might keep its decision-making authority in respect to marketing, and loose them in relation to, e.g., financial management. The question of whether acquired subsidiaries will keep their decision-making authority based on brand ownership must consequently dependent on whether brands are location-bound (Rugman and Verbeke, 2001), or brandrelated value will be destroyed if centralization is emphasized by the acquiring $\mathrm{MNC}$ (Haspeslagh and Jemison, 1991). 


\section{Methodology}

Given the limited amount of knowledge on the role of brands as a critical resource subsidiaries might draw on, an exploratory case study approach was chosen to gather more data on the subject (Yin, 2003). Furthermore, this approach also supports the analysis of process phenomena (Pettigrew, 1990; Langley, 1999) such as the integration of subsidiaries over time. By adopting a process perspective, we are able to identify the conflict-ridden and non-linear phenomena of centralization and decentralization of decision-making authority which are made up by a series of events. In order to avoid "death by data asphyxiation" (Pettigrew, 1990, p. 281) we followed a focused approach (George and Bennett 2005), i.e. integration issues and the role specific brands played were of interest only, even though we attempted to maintain the richness of data serving as background information. We chose a very specific empirical setting to isolate brand ownership effects on integration by studying three breweries Heineken acquired in Europe during the 1990ies that differ with regard to their brands' reach (regional, national or international brands) and quality (mainstream or premium/speciality brands). Given the fact that there is a trend towards premium/specialty brands in the market, these brands turn out to be more valuable then mainstream brands (see figure 1).

$* * * * * * * * * * * * * * * * *$

Figure 1 about here

$* * * * * * * * * * * * * * * * *$

Even though we are analysing only one company, our analysis of three subsidiary integration processes allows for thorough within case comparison. Data was collected from company 
sources (of Heineken and the three acquired companies), encompassing annual reports, press releases, company newspapers and periodicals etc. In addition multiple secondary sources were used including the Zephyr database, national company handbooks as well as the LexisNexis database and the HWWA (Hamburg Institute of International Economics) press archive for an extensive news coverage. Some more specialised secondary sources such as company biographies and case studies (retrieved from the European Case Clearing house and Business Source Premier) were used too.

The multiple sources accessed provided a dense and overlapping information base, which minimized typical problems tied to the use of secondary data such as, measurement error, source bias, low reliability and, probably most important, missing match with the needs of the study (Emory and Cooper, 1991). With regard to the latter, it turned out that national and regional newspapers showed a particular great interest as to what happened to 'their' breweries and brands after being taken over. For these companies were often seen as part of a national or regional everyday culture.

Data was gathered for an extended period starting in the years before the take over up until ten or more years after the acquisition, to cope with long term integration effects. To enhance reliability of data analysis, author triangulation was applied (Houman-Anderson and Skaates, 2004). Even though interviews are often considered as a very important data source for case studies (Yin 2003, p. 89), we refrained from interviewing subsidiary managers as the period analysed (10 - 17 years) was very long and interviewees' responses might be prone to ex-post rationalization. Validity of the overall argument, however, was checked in an interview with a subsidiary manager of Heineken. 


\section{Heineken's overall (De)centralization policy}

In the late 1980s Heineken was considered as a decentralized company (Lawrence, 1991), basically confirming extant theory, which assumes that a European company active in the food and beverage industry, should be rather decentralized (c.f. Franko 1976, Bartlett and Ghosal 1989). Heineken has, though, changed its strategy tremendously since the 1980ies. A recent study comes to the conclusion that over the last decades a strong "Heinekenisation" has taken place in foreign operations (Elshof, 2005, p. 12). This includes a strong centralization of decision-making authority with regard to marketing issues (ibid.). Despite the fact that Heineken owns a large portfolio of 170 regional, national and speciality brands, the globally distributed brands 'Heineken' and 'Amstel' are still the most important revenue base for Heineken. They alone account for about 30 per cent of beer produced (in terms of volume) and they are highly profitable (Heineken, 2007). Thus "keeping the Heineken brand healthy and growing" is seen as vital (Heineken, 2007, p. 10). On this behalf, all marketing policy (including guidelines and standards for brand style, brand value and brand development) for the two global brands ('Heineken' and 'Amstel') is made at the headquarters. Headquarters, further, strongly controls and supports the local marketing of these brands (Elshof, 2005). In addition, a particular emphasis is put on so-called "top-line growth" (Heineken, 2007 p. 7), i.e. the marketing of higher priced premium and speciality beers with a high profit margin in expense of lower profitable beer types (standard, lowprice, trademarks). Therefore, Heineken motivates foreign subsidiaries to put strong emphasis on selling the global brands of Heineken.

Conformity to headquarters standards is secured by a huge army of expatriates. In 2002, a total of 260 expatriates mainly of Dutch nationality were employed in 62 countries (Heineken, 2002), with these managers switching their positions almost every five years 
(Fiedler, 2004). Therefore, decision-making authority at Heineken seemingly is highly centralized. The implementation of headquarters decisions in foreign subsidiaries are tightly monitored by direct personal control through expatriates. The question, however, remains to what extent overall centralization policy of Heineken is feasible in newly acquired subsidiaries that might own critical marketing resources. This will be looked at in more detail below studying the integration process of three recently acquired subsidiaries that differ in ownership of more or less valuable brands.

\section{Three case studies}

An overlooked aspect in the literature so far is subsidiary brands and its relationship to subsidiary decision-making authority. The basic question to be looked at throughout the cases is therefore, what effects do different kinds of brands (global-, local-, or specialty brands) have on the ability of subsidiaries to maintain decision-making authority after being acquired?

Heineken deliberately prefers to acquire small or medium sized companies (see table 1). Consequently, target firms only slightly differ with regard to size, volume and sales of the acquired companies. The three cases analysed below represent such rather small acquisitions. There is little difference among those three companies with regard to size, volume and sales, but there are differences with regard to their brand portfolio.

$* * * * * * * * * * * * * * * * * * * *$

Table 1 about here

$* * * * * * * * * * * * * * * * * * *$ 
The selected cases were:

- Calanda-Haldengut, a Swiss brewery company, acquired in 1993. This company operated two brands ('Calanda' and 'Haldengut') that are regional in scope and standard in quality.

- Zlatý Bažant of Slovakia, acquired in 1996. This company maintained a national premium brand ('Zlatý Bažant') that even was exported to neighbouring countries.

- Brasserie Fischer of France, also acquired in 1996. This company operated a specialty beer brand named 'Desperados' which gained strong popularity in many European countries in the acquisition year.

These three companies strongly represent the different types of companies Heineken has taken over in last decades (altogether Heineken has taken over 37 brewery companies in Europe from 1990-2008 (see table 1). They are also quite representative for the different kinds of brewery companies at sale on the European market. Table 2 gives an overview on some characteristics of the three newly acquired subsidiaries studied.

$* * * * * * * * * * * * * * * * *$

Table 2 about here

$* * * * * * * * * * * * * * * * *$

Case 1: Calanda Haldengut, Switzerland - regional/standard brands as a critical resource?

Heineken's take-over of Calanda Haldengut, a holding of two regional breweries in Switzerland, in 1993, was the first large foreign incursion into the Swiss beer market. Heineken had already acquired ten percent in the holding a few years before, presumably in order to achieve some control over its Swiss distributor of the Heineken brand. Calanda Haldengut was an important player on the Swiss beer market. It held a 12.5 per cent market share $(600,000 \mathrm{hl}$ in 1992) in the beer market of which $420,000 \mathrm{hl}$ were own brands. 
Additionally, it distributed and produced 600,000 hl soft drinks (e.g. by a licence production of Coca Cola).

The two brands 'Calanda' and 'Haldengut' appeared to be problematic being regional in scope and standard in quality. Second, the company struggled with a sluggish Swiss beer market. Furthermore, the Haldengut Holding, one of the holding partners and majority stakeholder in Calanda Haldengut, did not voluntarily search for an international partner, but was forced to do so, due to permanent liquidity problems. Therefore, some voices immediately urged that Heineken would be less interested in the development of the regional brands, but rather in the distribution network to channel Heineken beer to the Swiss market (Neue Zürcher Zeitung, December 24, 1993).

Subsequent to the take-over, Heineken management took control. First, Heineken Veteran Willem Hosang led the corporation followed in 2002 by Boudewijn van Rompu, former CEO of Heineken Vietnam. Then the typical Heineken acquisition-integration strategy was implemented including the sale of real estate property and unrelated businesses like soft drink production. Consolidation also affected the configuration of breweries. A focused investment policy towards the Calanda site in Chur led to the closure of the incumbent Haldengut brewery in Wintherthur in the realm of a Heineken-wide cost cutting program. Two years before, Heineken had acquired the rest of the outstanding shares and renamed the company to Heineken Switzerland AG.

The strategic alignment of the subsidiary's brand portfolio turned out to be a headquarters matter. It was Heineken's CEO, Karel Vursteen, who announced that Calanda and Haldengut would become national flagship brands and that this would be accompanied by an aggressive marketing campaign and improved service in gastronomy. Vursteen utterances, however, 
turned out to be rather non-binding for the decade to come. On the contrary, the subsidiary's brand portfolio suffered in that period of time from competition by genuine Heineken brands. In the following years, Heineken introduced an international premium brand ('Heineken'), an international standard brand ('Amstel') and a variety of specialty brands. 'Amstel' was introduced accompanied by a massive marketing effort and had been brewed in Chur from 1996. From a Calanda Haldengut point of view this move was conflicting, as 'Amstel' belonged to the same segment as the 'Calanda' and 'Haldengut' brands. As several annual reports indicate, 'Heineken' and 'Amstel' gained market share significantly in absolute and relative terms, whereas 'Calanda' and 'Haldengut' lost. Without additional support, 'Calanda' and 'Haldengut' sales decreased with the overall demand for standard beer. The growth of 'Heineken' justified its local production from 1998 onwards. From 1997, further specialty brands such as 'Ittinger Klosterbräu', 'Erdinger Weissbier' and alcohol-free 'Buckler' were imported.

The promise to launch either 'Calanda' or 'Haldengut' nationwide was only fulfilled in 2005, twelve years after the acquisition, but with meagre success only. Today, 'Calanda' and 'Haldengut' only account for about 2.7 per cent of the Swiss beer market each, whereas 'Heineken' has 9 per cent.

Summing up, the ownership of regional and standard beers did not impede the loss of subsidiary decision-making authority. Heineken supervises its Swiss business through expatriates and has merged various Swiss companies. The massive introduction of global brands such as 'Heineken' and 'Amstel', whose marketing strategy is defined at the headquarters, at the expense of regional brands, shows that the subsidiary lost decision making authority not only in deciding on important strategy-related areas, but also on matters related to the compilation of the subsidiary's brand portfolio. 


\section{Case 2: Heineken's Slovakian breweries - premium brands as a critical resource?}

The acquisition of a 66 per cent stake at the Slovakian corporation Zlatý Bažant was similar to the case of Calanda Haldengut with regard to the following features: Heineken was the first international player that invested into the country; Zláty Bazănt, like Calanda Haldengut, accounted for about 10 per cent of the market; and the output volume of Zlatý Bažant was only slightly higher than at Calanda Haldengut $(450,000 \mathrm{hl})$ in the acquisition year. Furthermore, both companies had to struggle with problems: Whereas Haldengut suffered from a liquidation crisis, Zlatý Bažant lost a 9 per cent market share between 1994 and 1995 due to a re-organization measure.

Beside these similarities, there were also some differences: First, Calanda Haldengut was located in a developed country with a mature market, whereas Zlatý Bažant was located in a transition economy with a growing market for beer (at least until 2003). Second, Zláty Bazănt owned a national premium brand ('Zlatý Bažant'), which had even been exported (e.g. to the Czech Republic). Additionally, Zlatý Bažant ran its own malt house beside the brewery.

As in the Swiss case, a manager with a strong Heineken background (Marc Bolland) became general director of Zlatý Bažant just after the take-over. Other Heineken managers followed (Jean Paul van Hollebeke and Dimitar Aleksiev). Financial management of the subsidiary has remained in Dutch hands until today.

Next to modernizing Zlatý Bažant and upgrading one of its brands, Heineken bought three other breweries (Corgon, Martin, Gemer) in Slovakia between 1997 and 2000. In 1999, marketing activities of Corgon and Zlatý Bažant were combined into a new company, called Heineken Slovensko. Martin and Gemer were also integrated into that company following 
their acquisition. When beer consumption went down due to an increase of alcohol taxes in 2003, the breweries at Corgon, Martin, Gemer were closed down and production was transferred to Hurbanovo, which remained the single Heineken production site in Slovakia. Until 2001, Heineken Slovensko delivered no profits, due to the large investments into the brewing and malting facilities. Today, Heineken Slovensko produces about $2 \mathrm{ml} \mathrm{hl}$ of beer per year and has a 37 per cent market share. Since 2003, the subsidiary is directly controlled by Austrian Brau Union, Heineken's regional Central and Eastern European headquarters.

Even though the introduction of global brands has been negligible compared to the Swiss case, the strategic alignment of Zláty Bazănt's endogenous brands was in this case also a headquarters' matter. In 1999, the subsidiary was forced by the headquarters to give up its successful license production of Gambrinus, a traditional Czech Pilsner. Today, Zláty Bazănt', now renamed Heineken Slovensko, sells similar brands from other Heineken Czech subsidiaries such as 'Krušovice' or 'Starobrno'. Further, 'Desperados' fills the gap left by a lack of indigenous Zláty Bazănt’ specialty brands.

Second, the headquarters took control over the repositioning of 'Zláty Bazănt'. It was introduced in other Central European countries, even though it was not well known until then. Following Marc Bolland, general director of Zlatý Bažant at that time: "an 'exotic brand from somewhere' [is] a good place to start" (Bolland cit. in Boland 1996). Thereby, headquarters decided on a re-launch of the familiar logo of 'Zláty Bazănt' (the pheasant, king of farmland birds) in order to make it more prominent and a little less mechanic. It is fair to say, therefore, that 'Zláty Bazănt' has become the 'Heineken' for Slovakia and neighbouring countries. Even though consumers may buy 'Heineken' and 'Amstel' in Slovakia, these brands do not belong to the top 20 beer brands in Slovakia. The Zlatý Bažant brands, however, account for 10.4 per cent of the Slovakian market. They are exported to USA, 
Canada, the Ukraine, Hungary, Lithuania, Latvia, Estonia, Moldavia, or Kazakhstan (Export) and produced under license in Poland, Czech Republic and Russia (Heineken Slovensko Homepage). Coincidently, cans of 'Zláty Bazănt' were upgraded in 2004 in regards of design and are now shining in new elegant green, the colour of Heineken.

The restructuring and integration process at the various Slovakian brewers acquired by Heineken was as fierce as in the Swiss case. Heineken personnel filled in CEO and Financial management positions, quickly closed down production sites and transferred brands to one single site. The Hurbanova site ('Zláty Bazănt') was spared from being closed down and has been even extended through new brewing and malting facilities.

In marketing affairs, Heineken headquarters took control over the strategic realignment of 'Zláty Bazănt'. 'Zlatý Bažant' was successfully integrated into Heineken's Central and Eastern European brand portfolio and plays a 'Heineken'-like role there, albeit at a regional level. However, the subsidiary itself had only little impact on these strategic decisions, they were assigned by the headquarters.

Case 3: Brasserie Fischer, France - Specialty brands as a critical resource?

Heineken was well established in France holding about 23 per cent market share and employing 3,700 people, when it acquired Brasserie Fischer and its subsidiary Societé Adelshoffen in 1996. At that time, Heineken, further, owned a brewery located in Schiltigheim, Brasserie Fischer's home base. The take-over was 1.3 billion FF worth and added 950 employees to the Heineken payroll in France. Together with a further acquisition in Northern France, Heineken's share in the French beer market rose to 30 per cent, securing its number two position behind market leader Danone (43 per cent). 
Brasserie Fischer was a pro-active company. For instance, Brasserie Fischer had developed a range of speciality beers of which 'Desperados' - an aromatized Tex-Mex beer introduced in 1995 - gained strong popularity in the acquisition year. This was exactly what lacked Heineken for quite some time: successful speciality brands that give access to young beer drinkers.

At first sight, the typical Heineken consolidation strategy was applied. Thus the brewery at Brasserie Fischer's subsidiary Adelshoffen was closed and its brands (e.g. 'Adelsscott') were transferred to the production site of Brasserie Fischer in Schiltigheim in 2000, which had already been upgraded in 1998. Moreover, the majority of the 250 distributors that were bound to Brasserie Fischer, were taken over in the wake of the acquisition and used to channel more Heineken Brands to the French customers (Kahlen, 2002).

Brasserie Fischers' breweries, though, have never produced 'Heineken', for this brand has been produced in other French sites of the corporation. Moreover, Brasserie Fischer has maintained relatively long its decision making authority, as Heineken allowed this subsidiary a "spécialiste des spécialites" status (La Tribune, November 13, 2001, p. 24). Thus Heineken for some time acknowledged Fischer's innovativeness and refrained from integrating the company into its regional holding in France, Sogebra. Fischer maintained its own R\&D centre and was planning two product innovations per year.

By doing so Heineken France developed Brasserie Fischer into a centre for beer mix drinks. The production of 'Desperados' that was now sold by the whole Heineken distribution network grew in importance in the Schiltigheim site at the expense of other beers (basically beers that belong to the Brasserie Fischer product portfolio). While this at first allowed for economies of scale it later-on created massive problems, when the beer mix drinks faced an 
increasing competition by numerous types of Alco-pops (Agence France Press, April 7, 2005). This led to a downturn in sales (50 per cent in the years 2003 and 2004) and to reorganizations, redundancies and finally to the integration of Brasserie Fischer into Sogebra and its loss of its own R\&D centre in 2005. This move went hand in hand with the creation of a marketing unit for speciality brands in the regional headquarters. Recently (in 2008), the Production site of Brasserie Fischer was closed down and the personnel partly transferred to Heineken's second subsidiary in Schiltigheim and its other French sites.

Summing up this case: With a time lag, Brasserie Fischer was, like in the two other cases, fully absorbed into Heineken's company network. Heineken's acknowledgment of Brasserie Fischer's innovativeness made the latter temporarily an exception to the rule, but dependency on one type of beverages, made the company vulnerable and prone to Heineken overall integration strategy.

\section{Discussion and Conclusion}

Table 2 gives a summary of the three cases studied. In all cases, we can see a high degree of integration and centralization of decision-making authority following acquisition. In two out of three cases, personal control was established right after the acquisition and has been maintained until today. In the third case (Brasserie Fischer), decision making authority at the beginning was surprisingly high, but later-on, all production sites were closed down and the brands were integrated into Heineken's regional division in France. In regard to marketing decisions, it is clear that the strategic decision of the brand portfolio, i.e. the question which brands are supposed to be maintained or introduced or which brands are worth being boosted by the company-wide distribution network is a headquarters matter. In the CalandaHaldengut case, it was clear that the introduction of the global brands, 'Heineken' and 'Amstel', was a top priority in expense of the regional standard brands. In the Slovakian 
case, Heineken decided over the brand portfolio in Slovakia, but also supported 'Zlatý Bažant' to become the 'Heineken' of Slovakia and its neighbouring countries. Brasserie Fischer had some decision-making authority in developing new beer mix beverages for the whole company network. However, decentralization happened rather as a consequence of acknowledging the subsidiary's innovativeness rather than owning a specific valuable brand. Dependency on beer mix beverages only revealed to be fatal for Fischer. Even though the faith of the brands had been very different in our three cases, the centralization of decision making at Heineken headquarters was largely the same in the long run.

$* * * * * * * * * * * * * * * * *$

Table 3 about here

$* * * * * * * * * * * * * * * * * *$

Taken together, the case studies demonstrate that brand ownership can hardly be seen as a critical resource, that empower newly acquired subsidiaries in the brewery industry. In all three cases studied, Heineken's strong overall centralization policy overruled subsidiary attempts to maintain autonomy. This extended to subsidiary management, which was replaced by Heineken personnel, to operations, that were streamlined by rationalization measures and plant closures, and in particular to brand ownership and brand-specific decision making competencies. With regard to the latter subsidiaries in the long run lost all strategic competencies (e.g the right to decide on the development of new and incumbent brands as well as the right to decide on the range and priority of brands distributed) with only a few operational competencies remaining at subsidiary level.

Interestingly the value of the brand did not make a difference here. More valuable brands such as 'Zláty Bazănt' that turned out to be international in reach, and premium in quality did 
not allow for a greater subsidiary decision-making authority than ,e.g., the regional/standard brand 'Calanda'. A somewhat deviant case here is the case of Brasserie Fischer, where headquarters centralization policy only occurred with a certain time lag. According to our impression however, it was not the availability of a successful speciality brand that initially blocked a centralization of decision making authority but - as mentioned above- the innovation capability of the subsidiary that is less portable and needs a higher level of absorptive capacity to be developed over time by the headquarters.

Looking into the reasons, why the brands studied here hardly turn out to serve as critical resources for newly acquired subsidiaries, the following points seem instructive. First, as many contributions from the global marketing literature have set out, the consumption of beer, as a culturally sensitive product, is highly subject to country-of-origin effects (Schaefer, 1997; Phau and Suntornnond, 2006; Dawes, 2008). In other words the national origin of a product implies a strong preference of customers. Sometimes even the city-of-origin is playing an important role (Lentz et al., 2007). However taking into consideration the results from our case studies, national or local origin is clearly not associated with subsidiary ownership and only loosely associated with the spatial dimension of where the branded product is produced. Concentration of production, at least at national level, seems not to harm customers brand loyalty.

Second, while more traditional consumers stick to incumbent national brands - or at least to brands that successfully carry this image - especially younger consumers feel more inclined to accept global brands such as 'Heineken' or 'Amstel' next to or as a substitute for national or regional brands. This trend of cross border sub-cultural consumer behaviour (Welge and Holtbrügge, 1999) is generally weakening the role of national and regional brands as a power 
resource for subsidiaries since it genuinely supports and justifies the introduction of headquarters' global brands.

Third, the case studies also demonstrate that Heineken is following a very careful policy in changing and re-launching incumbent brand images. Moreover, ultimate ownership information is not indicated at all on the products or in a rather hidden way to avoid brand corrosion.

Fourth, in line with overall findings on the transfer of marketing knowledge (Schlegelmilch and Chini, 2003) brand related knowledge seem to be rather easy to transfer from the subsidiary to the headquarters. In terms of Rugman and Verbeke (2001) the brand and the brand image itself seem to codify the many tacit and fundamentally context specific knowledge associated with selling a particular type of beer. Other knowledge associated with marketing beer - e.g. specific advertising, event marketing - is not specialized to the subsidiary, rather nationally (if at all). 


\section{Literature}

Baliga, B. R. and Jaeger, A. M. (1984) 'Multinational corporations: control systems and delegation issues', Journal of International Business Studies, Vol. 15 (fall) 25-40.

Bartlett, C. A. and Ghoshal, S. (1989) Managing Across Borders. The Transnational Solution, Harvard Business School Press, Boston, MA.

Birkinshaw, J. and Hood, N. (1997) 'An empirical study of development processes in foreign-owned subsidiaries in Canada and Scotland', Management International Review, Vol. 37, No. 4, pp. 339-364.

Boland, V. (1996). 'Heineken Aims to Refresh Parts of Slovakian Brewer: Dutch Controller has Provided Technology and Marketing', Financial Times, August 30, 1996, p. 19.

Bouquet, C. and Birkinshaw, J. (2008) 'Managing power in the multinational corporation: how lowpower actors gain influence', Journal of Management Studies, Vol. 34, No.3, pp. 477-508.

Cheng, J.L.C. (2007) 'Critical issues in international management research: an agenda for future advancement', European J. International Management, Vol. 1, Nos 1/2, pp. 23-38.

Dawes, J. (2008) 'Regularities in buyer behaviour and brand performance: the case of Australian beer', Brand Management, Vol. 15, No. 3, pp. 198-208.

Doz, Y. and Prahalad, C.K. (1981) 'Headquarters influence and strategic control in MNCs', Sloan Management Review, Vol. 23, No.1, pp. 15-29.

Dunning, J.H. (1958) American Investment in British Manufacturing Industry, Allen and Unwin, London.

Egelhoff, W.G., Gorman, L. and McCormick, S. (1998) 'Using Technology as a Path to Subsidiary Development', in J. Birkinshaw and N. Hood (Eds.): Multinational Corporate Evolution and Subsidiary Development, Macmillan Press, Houndsmill, Bas., pp. 213-238.

Elshof, P. (2005). Heineken N.V. Company Profile, mimeo, Food world research \& consultancy.

Emory, C.W. and Cooper, D.R. (1991) Business Research Methods Irwin Homewood.

Fiedler, A. (2004). "Wir werden in nächster Zeit aggressiver". Interview with Boudewijn van Rompu, Sonntagszeitung, September 12, 2004, p. 77.

Franko, L. G. (1976) The European Multinationals, Harper and Row, London.

Gates, S. and Egelhoff, W. (1986) 'Centralization in headquarters-subsidiary relations', Journal of International Business Studies, Vol. 17, No.2, pp. 71-92.

George, A. L. and Bennett, A. (2005) Case Studies and Theory Development in the Social Sciences, MIT Press, Cambridge.

Goehle, D.G. (1980) Decision making in Multinational Corporations, Ann Arbor: UMI Research Press

Haspeslagh, P. and Jemison, D. (1991) Managing Acquisitions - Creating Value through Corporate Renewal, The Free Press, Oxford.

Hedlund, G. (1986) 'The hypermodern MNC - a heterarchy?', Human Resource Management, Vol. 25, No.1, pp. 9-35.

Heineken annual reports 2001, 2003, 2004, 2005, 2006, 2007

Houman-Andersen, P. and Skaates, M.A. (2004) 'Ensuring validity in qualitative international business research', In Marschan-Piekkari, R. and Welch, C. (Eds.): Handbook of Qualitative Research Methods for International Business, Edward Elgar, Cheltenham and Northampton, pp. 464-485.

Kahlen, C. (2002). „Grossisten unter Druck“, Lebensmittel-Zeitung, July 26, 2002, 33. 
Kotthoff, H. (2001) 'Pluri-local Social Spaces in Global Operating German Companies', in Pries, L. (Ed.): New Transnational Social Space: International Migration and Transnational Companies in the Early Twenty-First Century, Routledge, London and New York, pp. 134144.

Langley, A. (1999) 'Strategies for Theorizing from Process Data', Academy of Management Review, Vol. 24, No. 4, pp. 691-710.

La Tribune (2001). Bas-Rhin - Le Brasseur Fischer investit dans l'innovation, November 13, p. 24.

Lawrence, P. (1991), Management in the Netherlands, Clarendon Press, Oxford.

Lentz, P., Holzmüller, H. and Schirrmann, E. (2007) 'City of origin effects in the German beer market: transferring an international construct to a local context', Advances in International Marketing, Vol. 17, pp. 251-274.

Marinov, M.A. and Marinova, S.T. (1999) 'Foreign investor strategy development in the Central and Eastern European context', Thunderbird International Business Review, Vol. 41, No.1, pp. 107-130.

Mayrhofer, W. (2007) 'European comparative management research: towards a research agenda'. European J. International Management, Vol. 1, No. 3, pp. 191-205.

McKern, B. and Naman, J. (2003). The role of the Corporate Center in Diversified International Corporations. In: B. McKern.(ed.), Managing the Global Network Corporation. London: Routledge, 220-259.

Meyer, K. (2007) 'Acquisition as an Entry and Growth Strategy', in Meyer, K. E. and Estrin, S. (Eds): Acquisition Strategies in European Emerging Economies, Palgrave, Basingstoke, pp. 43-57

Meyer, K. and Tran, Y.T.T. (2006) 'Market penetration and acquisition strategies for emerging economies', Long Range Planning, Vol. 39. No.2, pp.177-197.

$\mathrm{Mu}$, S., Gnyawali, D. and Hatfield, D. (2007) 'Foreign subsidiaries learning from local environments: an empirical test', Management International Review, Vol. 47, No.1, pp. 79-102.

O'Donnell, S. (2000) 'Managing foreign subsidiaries: agents of headquarters, or an interdependent network?', Strategic Management Journal, Vol. 21, No.5, pp. 525-548.

Oesterle, J-M. and Laudien, S. (2007) 'The future of international business research and the relevance gap: a German perspective, European Journal of International Management, Vol. 1, Nos. 1/2, pp. 39-52.

Papanastassiou, M. and Pearce, R. (2005) 'Technology sourcing in multinational enterprises and the roles of subsidiaries: an empirical investigation', International Business Review, Vol. 14, No. 3, pp. 249-267.

Paruchuri, S., Nerkar, A. \& Hambrick, D. C. (2006) 'Acquisition integration and productivity losses in the technical core: disruption of inventors in acquired companies', Organization Science, Vol. 17, No. 5, pp. 545-562.

Pettigrew, A. M. (1990) 'Longitudinal Field Research on Change: Theory and Practice', Organization Science, Vol. 1, No. 3, Special Issue: Longitudinal Field Research Methods for Studying Processes of Organizational Change, pp. 267-292.

Pfeffer, J. and Salancik, G.R. (1978) The External Controls of Organizations - A Resource Dependence Perspective Harper \& Row Publishers, New York.

Phau, I. and Suntornnond, V. (2006) 'Dimensions of consumer knowledge and its impact on country of origin effects among Australian consumers', Journal of Consumer Marketing, Vol. 23, No. 1, pp.34-42.

Rugman, A. M. and Verbeke, A. (2001) 'Subsidiary-specific advantages in multinational enterprises', Strategic Management Journal, Vol. 22, pp. 237-250. 
Schaefer, A. (1997) 'Consumer knowledge and country of origin effect', European Journal of Marketing, Vol. 31, No.1, pp. 56-72.

Schlegelmilch, B. and Chini, T. (2003) 'Knowledge transfer between marketing functions in multinational companies: a conceptual model', International Business Review, Vol. 12, pp. 215-232.

Schweizer, L. (2005) 'Organizational integration of acquired biotechnology companies into pharmaceutical companies: the need for a hybrid approach', Academy of Management Journal, Vol. 48, No.6, pp.1051-1074.

Vachani, S. (1999) 'Global diversification's effect on multinational subsidiariy autonomy' International Business Review, Vol. 8, pp. 535-560.

van Rompu, B. (2004). "Wir werden in nächster Zeit aggressiver, Interview in Sonntagszeitung, September 12, 2004, 77.

Welge, M.K. and Holtbrügge, D. (1999) 'International management under postmodern conditions', Management International Review, Vol. 39, No.4, pp. 305-322.

Yin, R. K. (2003) Case Study Research. Design and Methods, Third Edition, SAGE Publication, Thousand Oaks, London and New Dehli.

Young, S. and Tavares, A. T. (2004) 'Centralization and autonomy: back to the future, International Business Review, Vol. 13, pp. 215-237. 


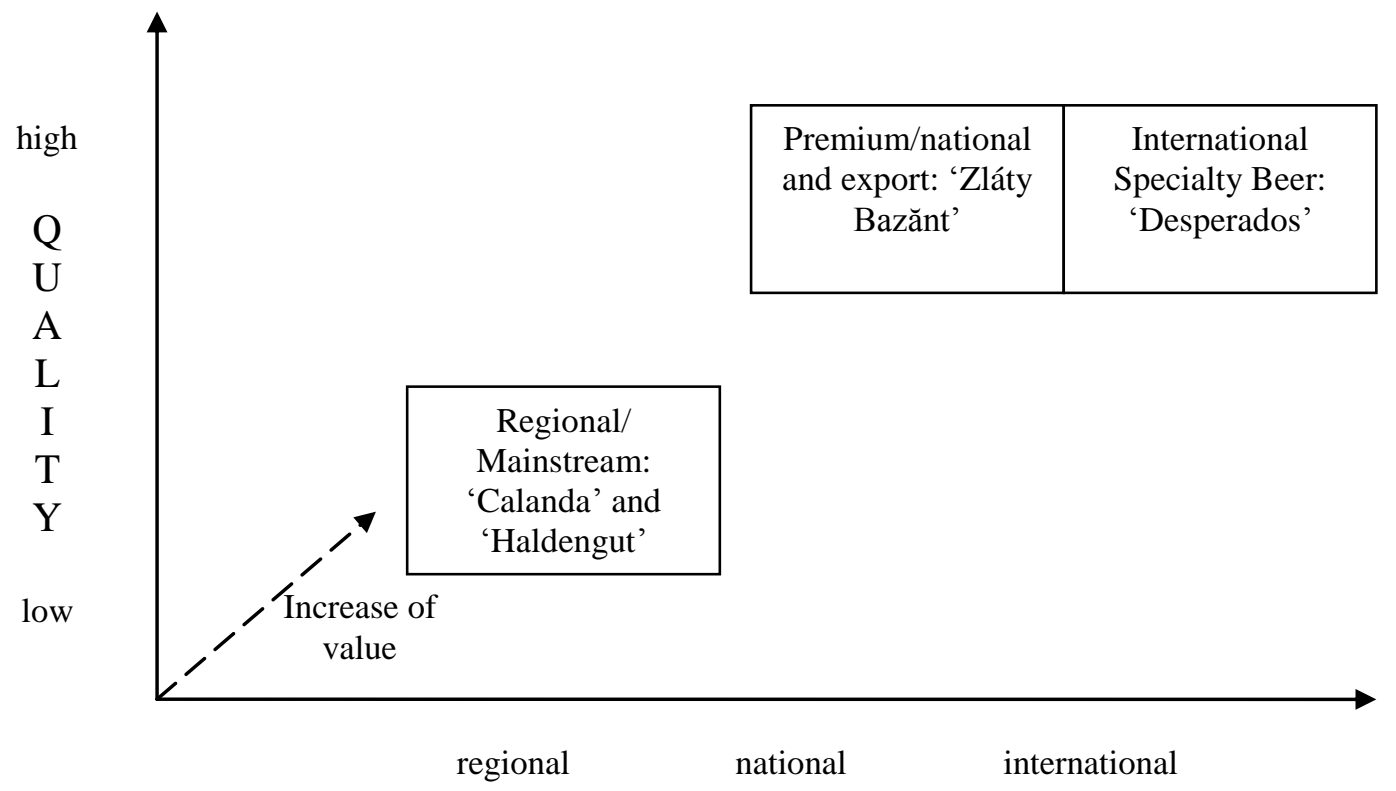

GEOGRAPHIC REACH 
Table 1 - Heineken's acquistions in Europe 1990-2008 (June)

\begin{tabular}{|c|c|c|c|c|}
\hline Company & Country & Year & $\begin{array}{c}\text { First stake in } \\
\text { per cent }\end{array}$ & $\begin{array}{l}\text { Sales volume (in } \\
\text { mil hl) in year } \\
\text { before acquisition }\end{array}$ \\
\hline Komaromi Sorgyar RT & Hungary & 1991 & 50.3 & 0,35 \\
\hline Le Cave de Chalet & France & 1993 & 83.0 & n.a. \\
\hline Calanda-Haldengut & Switzerland & 1993 & 52.3 & 1.20 \\
\hline Zagorka-Brauerei & Bulgaria & 1994 & 80.0 & 0,97 \\
\hline Grupa Zywiec & Poland & 1994 & 24.9 & 2,0 \\
\hline Interbrew Italia & Italy & 1995 & 100.0 & n.a. \\
\hline Zlatý Bazant & Slovakia & 1995 & 66.0 & 0.45 \\
\hline Brasserie Fischer & France & 1996 & 54.4 & 1.70 \\
\hline Saint Arnould & France & 1996 & 66.0 & 1.40 \\
\hline Birra Moretti SpA & Italy & 1996 & 100.0 & 1.50 \\
\hline Ariana & Bulgaria & 1997 & 64.5 & n.a. \\
\hline Karsay & Slovakia & 1998 & 49.0 & 0.50 \\
\hline $\begin{array}{l}\text { Affligem Brouwerij } \\
\text { BDS NV }\end{array}$ & Belgium & 2000 & 50.0 & 0.07 \\
\hline Gemer & Slovakia & 2000 & 52.8 & 0.25 \\
\hline Martiner & Slovakia & 2000 & 51.0 & 0.32 \\
\hline Cruzcampo SA & Spain & 2000 & 88.2 & 6.00 \\
\hline $\begin{array}{l}\text { Brau Holding } \\
\text { International AG }\end{array}$ & Germany & 2001 & 49.9 & 10.50 \\
\hline $\begin{array}{l}\text { Karlsberg International } \\
\text { Brand GmbH }\end{array}$ & Germany & 2002 & 40.0 & 4.90 \\
\hline Bravo International & Russia & 2002 & 100.0 & 2.90 \\
\hline Hoepfner & Germany & 2004 & 100.0 & 0.20 \\
\hline $\begin{array}{l}\text { Fürstlich } \\
\text { Fürstenbergische } \\
\text { Brauerei KG }\end{array}$ & Germany & 2004 & 100.0 & 0.70 \\
\hline BBAG /Brau Union & Austria & 2004 & MAJ & 16.00 \\
\hline SOBOL Beer LLC & Russia & 2004 & 100.0 & 0.20 \\
\hline $\begin{array}{l}\text { Central European } \\
\text { Brewing Group } \\
\text { (CEBCO) }\end{array}$ & Russia & 2004 & 100.0 & 1.80 \\
\hline VINAP & Russia & 2004 & 100.0 & n.a. \\
\hline Würzburger Hofbräu & Germany & 2005 & 90.7 & 0.36 \\
\hline Baikal Brewery JSC & Russia & 2005 & 100.0 & 0.58 \\
\hline Patra Brewery & Russia & 2005 & 100.0 & 0.77 \\
\hline $\begin{array}{l}\text { Pivovarni Ivana } \\
\text { Taranova }\end{array}$ & Russia & 2005 & 100.0 & 0.29 \\
\hline Stepan Razin & Russia & 2006 & 100.0 & 1.40 \\
\hline Krušovice & $\begin{array}{c}\text { Czech } \\
\text { Republic }\end{array}$ & 2007 & 100.0 & 0.70 \\
\hline Rodic & Serbia & 2007 & n.a. & 0.50 \\
\hline $\begin{array}{l}\text { Scottish \& Newcastle } \\
\text { (various country } \\
\text { businesses) }\end{array}$ & UK & 2008 & 100.0 & 29.7 (excl. BBH) \\
\hline Bere Mures & Romania & 2008 & n.a. & 1.20 \\
\hline Drinks Union & $\begin{array}{c}\text { Czech } \\
\text { Republic }\end{array}$ & 2008 & 100.0 & 1.90 \\
\hline Rechitsa & Belarus & 2008 & n.a. & 0.29 \\
\hline Eichhof & Switzerland & 2008 & 96.5 & n.a. \\
\hline
\end{tabular}


Table 2: Characteristics of case study companies in the year before acquisition

\begin{tabular}{|c|c|c|c|c|}
\hline & \multicolumn{3}{|c|}{ SIZE } & \multirow[b]{2}{*}{ BRANDS } \\
\hline & $\begin{array}{l}\text { Volume in mil. } \\
\mathrm{hl}\end{array}$ & $\begin{array}{c}\text { Sales in mil. } \\
\text { \$US }\end{array}$ & $\begin{array}{l}\text { Number of } \\
\text { employees }\end{array}$ & \\
\hline $\begin{array}{l}\text { Calanda } \\
\text { Haldengut }\end{array}$ & $\begin{array}{c}1.20 \text { (of which } \\
0.6 \text { are beer) }\end{array}$ & 165.8 & n.a. & $\begin{array}{c}\text { Regional } \\
\text { mainstream } \\
\text { brands: } \\
\text { Calanda } \text { and } \\
\text { Haldengut } \\
\end{array}$ \\
\hline Zláty Bazănt & 0.45 & 20.6 & 600 & $\begin{array}{c}\text { National/intern. } \\
\text { premium brand: } \\
\text { Zláty Bazănt }\end{array}$ \\
\hline $\begin{array}{l}\text { Brasserie } \\
\text { Fischer }\end{array}$ & 1.70 & 222.7 & 950 & $\begin{array}{c}\text { International } \\
\text { specialty brand: } \\
\text { Desperados }\end{array}$ \\
\hline
\end{tabular}

Table 3: Integration processes and decision-making authority

\begin{tabular}{|l|c|c|c|}
\hline Company & $\begin{array}{c}\text { Overall } \\
\text { Integration and } \\
\text { Streamlining }\end{array}$ & $\begin{array}{c}\text { Centralization of } \\
\text { strategic marketing } \\
\text { decision }\end{array}$ & $\begin{array}{c}\text { How Heineken has } \\
\text { proceeded with the brand... }\end{array}$ \\
\hline $\begin{array}{l}\text { Calanda- } \\
\text { Haldengut }\end{array}$ & High & High & Begligence \\
\hline Zláty Bazănt & High & High & Boost \\
\hline $\begin{array}{l}\text { Brasserie } \\
\text { Fischer }\end{array}$ & $\begin{array}{c}\text { First: Low } \\
\text { Today: High }\end{array}$ & $\begin{array}{c}\text { First: low } \\
\text { Today: High }\end{array}$ & responsibilities \\
\hline
\end{tabular}

